\title{
IMPLEMENTASI ASAS EQUALITY BEFORE THE LAW DALAM PENYELESAIAN PERSELISIHAN HUBUNGAN INDUSTRIAL DI PENGADILAN HUBUNGAN INDUSTRIAL (PHI)
}

\begin{abstract}
Supono', Yos Johan Utama ${ }^{2}$
Abstrak

Negara Indonesia adalah Negara hukum. Salah satu prinsip Negara hukum adalah adanya jaminan penyelenggaraan kekuasaan lembaga peradilan yang merdeka, bebas dari segala campur tangan pihak kekusaan ekstra yudisial.. Kekuasaan kehakiman sendiri merupakan kekuasaan yang merdeka, yang salah satunya melalui Asas Objektivitas yang menghendaki bahwa penyelesaian sengketa akan baik dan dapat diterima oleh semua pihak, jika dilakukan secara imparsial (tidak memihak), objektif dan adil. Harapan- harapan di atas, muncul dari adanya Asas

Equality Before The Law yang merupakan salah satu dari tiga arti dari Rule of Law (Negara Hukium). Asas Equality Before The Law timbul dari sistem hukum modern yang diilhami oleh paradigma Positivisme yang beranggapan bahwa hukum itu harus objektif dan steril dari pengaruh apapun di luar hukum. Implementasi Asas Equality

Before The Law dalam penyelesaian perselisihan hubungan industrial di PHI ini menarik untuk diteliti lebih lanjut, karena Pihak yang berselisih dalam hubungan industrial adalah pengusaha dan pekerja/buruh yang secara sosial maupun ekonomi jelaslah "tidak sederajat". Metode Pendekatan yang digunakan dalam penelitian ini adalah metode pendekatan Sosio-legal (Socio-legal approach), yaitu metode penelitian hukum yang disamping menganalisa implementasi asas Equality Before The Law dalam hukum normative yang diberlakukan yaitu UU.No. 2 tahun 2004. Melalui penelitian ini dapat menemukan konsep peradilan hubungan industrial yang mampu menerapkan asas Equality Before The Law yang ideal.
\end{abstract}

Kata kunci: Hubungan industrial, Pengadlan Hubungan Industrial (PHI), asas Equality Before The Law.

\footnotetext{
${ }^{1}$ Mahasiswa Program Studi Magister IImu Hukum UNDIP

${ }^{2}$ Dosen Program Studi Magister IImu Hukum UNDIP
} 


\begin{abstract}
Indonesia is state law. One of the rule of law is the guarantee of the implementation of the power of the judiciary is independent, free from any interference from extrajudicial. Judicial power itself an independent power, whichone of them through the principle of objectivity requires that dispute resolution will be good and acceptable to all parties, if conducted impartially (unbiased), objective and fair. Above expectations, arises from the principle of Equality Before The Law, which is one of the three meanings of the Rule of Law (State Hukium). The principle of equality before the law a rising from the modern legal system inspired by positivism paradigm that assumes that the law should be objective and free from any influence outside the law. Implementation of the principle of Equality Before The Law on settlement of industrial relation dispute in Industrial Relation Court is interesting to study further, because the parties to the industrial relations disputes are the employers and workers/laborers who are socially and economically obviously "not equal". Method of approach used inthis study is the method of Socio-legal approaches (Socio-legal approach), whichin addition to legal research methods to analyze the implementation of the principle of Equality Before The Law on normative law enacted that law. No. 2 of 2004.Through this research can find the concept of industrial relations court is able to apply the principles of Equality Before TheLaw is ideal.
\end{abstract}

Keywords : Industrial Relations, Industrial Relations Court, The Principle of Equality Before The Law 


\section{A. Latar Belakang}

Pasal 1 ayat (3) UUD

NRI Tahun 1945 mengatur

bahwa: "Negara Indonesia

adalah Negara hukum”. Salah

satu prinsip negara hukum adalah

adanya jaminan penyelenggaraan

kekuasaan lembaga peradilan

yang merdeka, bebas dari segala

campur tangan pihak kekuasaan

ekstrayudisial untuk

menyelenggarakan peradilan

guna menegakkan ketertiban,

keadilan, kebenaran dan

kepastian hukum yang mampu

memberikan pengayoman kepada

masyarakat. $^{3} \quad$ Penyelenggaraan

peradilan haruslah berdasarkan

asas-asas kekuasan kehakiman

yang merdeka, salah satunya

adalah Asas Objektivitas. Asas

3 Rimdan, 2012, Kekuasaan Kehakiman PascaAmandemen Konstitusi, Jakarta, Kencana Prenada Media Group, hlm. 1 ini menghendaki bahwa

penyelesaian sengketa akan baik dan dapat diterima oleh semua pihak, jika dilakukan secara imparsial (tidak memihak), objektif dan adil. Oleh sebab itu, hakim adalah pejabat negara yang tugas utamanya memberikan penyelesaian definitive terhadap konflik atau sengketa antar warga masyarakat dan pemerintah yang dihadapkan kepadanya secara imparsial, objektif, adil dan manusiawi. ${ }^{4}$

Penyelesaian perkara secara objektif dan tidak memihak dilandasi oleh Pasal 4 ayat (1) Undang-Undang Nomor 48 Tahun 2009 yang menegaskan bahwa "Pengadilan mengadili

\footnotetext{
${ }^{4}$ Arief Shidarta, 22-24 Juni 2011, Sebuah Catatan tentang Hakim, Makalah pada Lokakarya Peningkatan Kapasitas Hakim, Hotel Apita, Cirebon, hlm. 2
} 
menurut hukum dengan tidak

membeda-bedakan orang”.

Artinya, hakim dalam memeriksa

dan memutus perkara yang

diajukan kepadanya haruslah

objektif dan tidak boleh memihak

kepada pihak tertentu. Hal ini

muncul sebagai akibat dari

adanya Asas Equality Before the

Law yang dikemukakan oleh

Albert Venn Dicey. ${ }^{5}$ Salah satu

dasar pikir utama asas Equality

Before the Law adalah hukum itu

harus steril dari kepentingan

sehingga harus objektif dan tidak

boleh memihak. Namun, bila

melihat kenyataan adanya

hubungan-hubungan yang dapat

menimbulkan hubungan hukum,

maka berpotensi pula timbulnya

${ }^{5}$ AlbertVenn Divey, 1915, Introduction to the Study of the Law of the Contitution, London Mcmilian, hlm. 110-115 konflik, seperti hubungan kerja

antara pengusaha dengan para pekerja/buruh, yang disebut sebagai konflik/perselisihan hubungan industrial.

Penyelesaian perselisihan hubungan industrial dilakukan di Pengadilan Hubungan Industrial (PHI) sebagai sebuah institusi/lembaga yang yang diharapkan mampu menyelesaikan perselisihan hubungan industrial yang cepat, tepat, adil dan murah sebagaimana yang diamanatkan oleh Pasal 56 Undang-Undang No. 2 Tahun 2004 tentang Penyelesaian Perselisihan Hubungan Industrial (selanjutnya disebut dengan UU No. 2 Tahun 2004). Di sini pengadilan haruslah netral, objektif dan tidak boleh memihak salah satu pihak 


\begin{tabular}{|c|c|}
\hline yang berselisih, & Penyelesaian \\
\hline kedudukan antara buruh dan & Hubungan Industrial? \\
\hline pengusaha sangat berbeda secara & bagaimana \\
\hline ekonomi/tidak & beracara di PHI yang mampu \\
\hline Berdasarkan uraian di atas, maka & menerapkan \\
\hline penulis tertarik untuk membahas & Before The Law yang ideal? \\
\hline mengenai: pertama, bagaimana & B. Metode Penelitian \\
\hline kedudukan Pengadilan Hubungan & Metode Pendekatan yang \\
\hline Industrial (PHI) sebagai salah & digunakan dalam penelitian ini \\
\hline satu institusi dalam penyelesaian & adalah metode \\
\hline masalah perselisihan hubungan & Sosiolegal (Socio-legal approach), \\
\hline industrial selain Arbitrase dan & yaitu metode penelitian hukum \\
\hline setelah Konsiliasi ataupun & yang menganalisis implementasi \\
\hline Mediasi? Kedua, Bagaimana & asas Equality Before The Law \\
\hline keterkaitan antara Asas Equality & dalam hukum positifnya, yaitu UU \\
\hline Before The Law dengan & No. 2 Tahun 2004, juga meneliti \\
\hline beracara dalam & implementasi \\
\hline penyelesaian & Equality Before the Law dalam \\
\hline industrial di & praktek beracara di Pengadilan \\
\hline Pengadilan Hubungan Industrial & Hubungan Industrial sesuai UU \\
\hline (PHI) sebagaimana & tersebut yang dialami para pihak \\
\hline menurut Undang-Undang No. 2 & yang terkait, yaitu \\
\hline tentang & advokat/pengacara, \\
\hline
\end{tabular}


pengusaha/asosiasi pengusaha

maupun pekerja/buruh atau serikat

pekerja/buruh.

\section{Kerangka Teori}

Seiring

dengan

perkembangan reformasi, telah

diterbitkan UU No.13 Tahun 2003

tentang Ketenagakerjaan. Terkait

dengan penyelesaian perselisihan

hubungan industrial ini,

dicantumkan dalam Penjelasan

Umum UU No. 13 Tahun 2003,

kemudian diatur lebih lanjut pada

Pasal 136 UU No.13 Tahun 2003.

Konsekuensi logis adanya UU baru

ini, maka UU terdahulu, yaitu UU

No. 22 Tahun 1957 tentang

Penyelesaian Perselisihan

Perburuhan dan UU No. 12 Tahun

1964 tentang Pemutusan Hubungan

Kerja di Perusahaan Swasta, tidak

berlaku lagi. Kemudian, sekarang

telah diatur dalam UU No. 2 Tahun
2004 tentang Penyelesaian

Perselisihan Hubungan Industrial.

Ketentuan UU No. 2 Tahun 2004

telah memberikan beberapa

alternatif sebagai solusi bagaimana

penyelesaian perkara perselisihan

hubungan industrial.

Ada 3 (tiga) bentuk

polarisasi penyelesaian perkara

perselisihan hubungan industrial

menurut ketentuan UU No. 2

Tahun 2004, yaitu dapat dilakukan

melalui perundingan Bipartit,

Tripartit dan dapat pula melalui

PHI. ${ }^{6}$ Penyelesaian perselisihan

secara bipartit melalui perundingan

bipartit, sedangkan secara tripartit

dengan melibatkan orang ketiga

melalui Mediasi, Konsiliasi

maupun Arbirtrase. Bipartit dan

${ }^{6}$ M. Saleh \& Lilik, 2012, Seraut Wajah Pengadilan

Hubungan Industrial, Bandung, Citra Adlyta Abadi, hlm. 55 
tripartit ini merupakan

penyelesaian

perselisihan

hubungan industrial di luar pengadilan (non-litigasi).

PHI merupakan lembaga

terakhir dalam penyelesaian

perselisihan hubungan industrial

setelah Konsiliasi dan Mediasi, dan

Arbitrase, yang dibentuk

berdasarkan UU No. 2 Tahun 2004.

Eksistensi lembaga Pengadilan

Hubungan Industrial tercantum

pada Pasal 5, Pasal 14, Pasal 23

ayat (2) huruf e, dan Pasal 55 serta

Pasal 56 UU No. 2 Tahun 2004.

Pada Pasal 55 UU No. 2 Tahun

2004 disebutkan bahwa

"Pengadilan Hubungan Industrial

merupakan pengadilan khusus yang

berada di lingkungan peradilan

umum". Selanjutnya, mengenai

tugas dan kewenangan PHI, secara

ekspilist ditentukan pada Pasal 56
UU No. 2 Tahun 2004, yaitu memeriksa dan memutus: (a) Di tingkat pertama mengenai perselisihan hak; (b) Di tingkat pertama dan terakhir mengenai perselisihan kepentingan; (c) Di tingkat pertama pemutusan hubungan kerja; (d) Di tingkat pertama dan terakhir mengenai

perselisihan antar serikat pekerja/serikat buruh dalam satu perusahaan.

Kedudukan PHI sebagai bagian dari Pengadilan Negeri, maka PHI adalah bentuk pengadilan khusus dari Pengadilan Negeri (PN). Kompetensi PN meliputi perkara perdata dan perkara pidana. Terhadap pekara perdata, hakim PN hanya akan memutus sesuai yang dituntut oleh Penggugat, tidak boleh memberikan putusan lebih dari 
yang dituntut. PHI adalah bagian dari perkara ketenagekerjaan yang merupakan bagian dari hukum perdata. Prinsip dari norma hukum perdata adalah bersifat mengatur, dalam arti pihak- pihak bebas untuk membuat suatu aturan yang tertuang dalam klausula perjanjian asalkan tidak bertentangan dengan perundang- undangan, kesusilaan, dan kesopanan yang ada dalam masyarakat. $^{7}$

Kaitannya dengan implementasi asas Equality Before the Law di PHI, maka pembahasannya harus meliputi pula unsur-unsur dari sistem pengadilan yang dikembangkan dalam lembaga peradilan tersebut, yaitu meliputi unsur-unsur: struktur, substansi dan budaya hukum. ${ }^{8}$ Selanjutnya, berkenaan dengan hukum acara yang berlaku, sesuai dengan isi ketentuan Pasal 57 UU No. 2 Tahun 2004 disebutkan bahwa "Hukum acara yang berlaku pada Pengadilan Hubungan Industrial adalah hukum acara perdata yang berlaku pada Pengadilan dalam lingkungan Peradilan Umum, kecuali diatur khusus dalam undang-undang ini”. Namun, terdapat beberapa perbedaan ketentuan hukum acara yang berlaku di PHI sebagaimana yang tercantum dalam UU No. 2 Tahun 2004 dengan hukum acara perdata di Peradilan Umum (PN), meliputi hal-hal: Syarat gugatan, Tempat menggugat, Biaya perkara, Jenis acara, Perdamaian, Majelis

8 Yos Johan Utama, Menggugat Fungsi PTUN Sebagai Salah Satu Akses WN untuk mendapatkan Keadilan dalam Perkara Adm.Neg. Jurnal Hukum Vol. 10 No. 1.Maret 2007, hlm. 33 
hakim, Batas kewenangan, Kuasa

Hukum, Waktu memutus, Dasar

putusan, Penyampaian putusan,

Biaya eksekusi, Upaya hukum. ${ }^{9}$

D. Hasil dan Pembahasan

1. Kedudukan PHI sebagai

Salah Satu Institusi dalam

Penyelesaian Perselisihan

Hubungan Industrial

Berdasarkan hasil

penelitian didapatkan bahwa

Pertama, hampir sembilan dari

sepuluh Penggugat (90\%)

perkara perselisihan hubungan

industrial yang diajukan ke PHI

Jakarta Pusat diajukan oleh

Pekerja /Buruh. Kedua, bahwa

delapan dari sepuluh $(80 \%)$

perkara

adalah

perkara/perselisihan Pemutusan

Hubungan Kerja (PHK).

9 Juanda Pangaribuan, 2011, Kedudukan Dosen dalam Hukum Ketenagakerjaan, Jakarta, Bumi Intitama Sejahtera, hIm.119
Ketiga, bahwa empat dari sepuluh (36 \%) perkara dimenangkan oleh Pekerja/buruh sedangkan tiga dari sepuluh (31\%) perkara dimenangkan oleh Pengusaha. Sisanya sekitar tiga dari sepuluh (33\%) perkara/gugatan dikabulkan sebagian. Keempat, bahwa hampir delapan dari sepuluh $(80 \%)$ perkara yang diputus oleh PHI Jakarta Pusat diajukan upaya hukum berikutnya (Kasasi maupun PK).

Dari data-data di atas, dapat dilihat bahwa pekerja/buruh yang dominan/lebih banyak mengajukan perkara/gugatan di PHI. Hal ini dikarenakan bahwa pihak pekerja/buruh merasa pihak Pengusaha telah 
melakukan wanprestasi/cidera

janji atau perbuatan melawan

hukum. Sedangkan, dari jenis

perbuatan/perselisihan yang

dominan diajukan adalah PHK.

Artinya, dalam hubungan

industrial pada umumnya dan

hubungan kerja pada

khususnya, kasus PHK

merupakan kasus yang paling

sering dirasakan para pihak,

yang tidak dapat diselesaikan

melalui upaya non-ligitasi, baik

bipartite, mediasi, maupun

konsiliasi. Bredasarkan hasil

penelitian di atas, maka terlihat

betapa masalah PHK

merupakan kasus serius/penting

yang menimpa pekerja/buruh

dan dominan dilakukan oleh

pengusaha.

Dari hasil penelitian

tersebut ada 2 (dua) pertanyaan yang dapat diajukan, yaitu

Pertama, mengapa

mayoritas/dominan Subjek

Penggugat adalah

Pekerja/buruh. Kedua,

mengapa mayoritas/dominan

jenis perkara yang diajukan

adalah PHK. Berbeda dengan

kondisi pekerja/buruh,

sedangkan bagi Pengusaha,

keluarnya/diPHK-nya seorang

atau bahkan beberapa orang

pekerja/buruh, secara

manajemen (operasional

maupun keuangan) jarang

menimbulkan masalah yang

serius di kemudian hari bagi

kelangsungan hidup perusahaan

tersebut. Perbedaan

kondisi/posisi antara

pekerja/buruh dan pengusaha

yang demikian, ternyata juga

merupakan bukti bahwa dalam 
praktek Asas Equality Before

the Law cukup sulit diterapkan

dalam peradilan, termasuk

dalam proses PHK di PHI.

Memperkuat fakta ini, maka

dapat dikemukakan adanya 2

(dua) putusan Mahkamah

Agung, yaitu Putusan

Mahkamah Agung RI. No.

700/Pdt. Sus/2011 dan Putusan

Mahkamah Agung RI. No.

299/Pdt. Sus/2012, yang pada

intinya dalam kedua Putusan

Mahkamah Agung tersebut

mengabulkan PHK dikarenakan

hubungan industrial sudah tidak

lagi harmonis.

2. Keterkaitan antara Asas

Equality Before the Law

dengan Prosedur/Beracara

dalam

Penyelesaian

Perselisihan

Hubungan

Industrial di Pengadilan
Hubungan Industrial (PHI)

Sebagaimana Diatur Undang-

Undang No. 2 Tahun 2004

tentang

Penyelesaian

Perselisihan Hubungan

Industrial

Keterkaitan asas
Equality Before the Law

dengan prosedur beracara di

PHI (sesuai UU No. 2 Tahun

2004), sebagaimana yang

tercantum pada Pasal 57 UU

No. 2 Tahun 2004 yang

menyatakan bahwa Hukum

acara yang berlaku pada PHI

adalah Hukum Acara Perdata

yang berlaku di lingkungan

Peradilan Umum, kecuali

yang diatur secara khusus

dalam undang-undang ini.

Sedangkan, Hukum Acara

Perdata pada umumnya

diberlakukan dengan asumsi 
dan anggapan bahwa para

pihak yang berperkara dalam

posisi yang sederajat seimbang,

sehingga harus pula

diperlakukan sama baik dalam

hak dan kewajiban berperkara.

Pada kenyataannya, tentu sulit

untuk diterima jika kedua pihak

dalam perselisihan hubungan

Industrial (Pengusaha dan

Pekerja/buruh) yang jelas

"tidak sederajat" diperlakukan

sama, baik dalam hak maupun

kewajiban dalam berperkara di

pengadilan. Berkenaan dengan

hal tersebut, setelah dilakukan

analisis terhadap materi

UU.No. 2 Tahun 2004, dari

total jumlah isi seluruh

materinya, terdiri dari delapan

Bab dan 126 pasal, maka

diperoleh data dan fakta bahwa

beberapa isi pasal di bawah ini berkaitan dengan Asas Equality

Before the Law yaitu yang

berkenaan dengan: Biaya

perkara, Sumpah hakim,

Pengajuan gugatan,

Penyempurnaan gugatan,

Kuasa Hukum, Majelis hakim,

Proses Acara pemeriksaan dan

Upaya Hukum.

Adapun analisis

terhadap pasal-pasal UU No. 2

Tahun 2004 yang berkaitan

dengan asas Equality Before

the Law sebagai berikut:

a. Biaya Perkara (Pasal 58);

b. Sumpah Hakim (Pasal 60 ayat 1$)$;

c. Domisili gugatan (Pasal 81)

dan Gugatan Kolektif

(Pasal 84);

d. Penyempurnaan Gugatan

(Pasal 82 ayat 2);

e. Kuasa Hukum (Pasal 87); 
f. Majelis Hakim dan Hakim

Adhoc (Pasal 88 dan Pasal 92);

g. Proses/acara Pemeriksaan (Pasal 98 ayat 1); dan

h. Upaya Hukum (Pasal 56).

3. Konsep Beracara di

Pengadilan

Hubungan

Industrial

(PHI) yang

Mampu Menerapkan Asas

Equality Before the Law yang

Ideal dan Kendalanya.

Setidaknya terdapat 2

(dua) kondisi yang harus

diperhatikan berkaitan dengan

ketidaksembangan kondisi

antara pihak pemgusha dengan

pekerja/buruh pada saat

berhadapan di PHI, yaitu:

a. Perbedaan kemampuan

ekonomi (kaitan adanya

faktor biaya)

Perbedaan kemampuan ekonomi antara Pengusaha

dengan pekerja/buruh

ternyata berpengaruh besar

dalam proses persidangan,

khususnya berkaitan

dengan kegiatan

persidangan, seperti:

memilih tempat pengajuan

gugatan, memanfaatkan

jasa kuasa hukum,

lama/waktu persidangan

yang

sulit

dipersingkat/disederhanaka

$\mathrm{n}$, termasuk di dalamnya

ada upaya kasasi ke

Mahkamah Agung (MA)

untuk perselisihan hak dan

perselisihan PHK. Di

samping itu, kewajiban

menempel materai Rp.

6000,- pada setiap bukti

dokumen/surat yang

diajukan. Hal ini cukup 
memberatkan

pekerja/buruh, tetapi tidak

demikian bagi pengusaha.

Para pekerja/buruh

biasanya/kebanyakan sudah

tidak punya penghasilan

lagi, tetapi perkaranya

diajukan dan diproses di

PHI.

b. Perbedaan kewajiban atas

kepemilikan dan

penyimpanan dokumen

(kaitannya dengan proses

pembuktian)

Seperti diketahui bahwa

adanya ketentuan bagi

perusahaan yang wajib

memiliki dan menyimpan

dokumen perusahaan

sedemikian rupa, sehingga

sewaktu-waktu dapat

diketahui

kondisi

perusahaan

beserta aktivitasnya

dalam

menjalankan perusahaan,

termasuk dalam

pengelolaan sumber daya

manusianya. Oleh karena

itu, dalam banyak kondisi,

maka

dokumen

ketenagakerjaan pun

seringkali hanya dimiliki

dan disimpan oleh

perusahaan. Proses

pembuktian kondisi ini jelas

menguntungkan pihak

Pengusaha. Sebaliknya, jika

tidak memiliki dokumen

pendukung, maka kondisi

ini akan melemahkan posisi

pekerja/buruh. Oleh karena

itu, sebaiknya ada

pembedaan pembuktian

antara pengusaha dengan

pekerja/buruh, dimana

dalam hal pembuktian 
surat/dokumen, maka beban

pembuktian tersebut wajar diletakkan lebih pada

pengusaha daripada

pekerja/buruh.

c. Pengeloaan/pengaturan Ijin

Karyawan SDM

Selama waktu hubungan

kerja, terutama saat

melakukan pekerjaan, maka

sepenuhnya hal tersebut

merupakan

hak/kewenangan

Pengusaha, khususnya

otoritas permohonan ijin

bagi karyawannya. Dalam

konteks ini, maka yang

perlu diperhatikan adalah

saksi-saksi yang lebih tahu

dan terlibat dalam

perselisihan hubungan

industrial pasti lah para

pekerja tersebut. Oleh karena itu, dalam hal diperlukan saksi-saksi yang meringankan/membela pihak Pekerja yang sedang berselisih, maka hal ini bukanlah hal susah untuk diberikannya ijin kepada Pengusaha dengan alasan kesibukan pekerjaan. Namun sebalilknya, pihak Pengusaha dengan mudahnya akan berusaha menghadirkan saksi-saksi yang mendukung pihak Pengusaha.

Berdasarkan uraian di atas, maka dapat diusulkan prosedur beracara yang mampu menerapkan/implementasik an asas Equality Before The Law yang ideal sebagai berikut: Biaya Perkara tidak 
dibatasi, Kuasa Hukum

gratis, Pengajuan gugatan

di tempat Tergugat, Majelis

Hakim permanen; Acara

pemeriksaan cepat/Acara

permeriksaan

disederhanakan,

Pembuktian

Tertulis

(Dokumen surat), Saksi-

saksi lebih dibebankan

kepada Pengusaha, dan

Upaya Hukum dibatasi.

\section{E. Simpulan}

PHI telah berusaha menerapkan asas Equality Before the Law semaksimal mungkin walaupun dirasakan masih jauh dari harapan pencari keadilan (pengusaha dan pekerja/buruh).

Salah satu faktanya adalah posisi pihak pengusaha terlihat lebih kuat, dalam hal pengusaha memperjuangkan maksudnya untuk melakukan PHK dengan alasan hubungan industrial sudah tidak harmonis, walaupun masih ada keinginan pihak pekerja/buruh untuk bekerja. Keterkaitan antara asas Equality Before the Law dengan prosedur/beracara dalam penyelesaian perselisihan hubungan industrial di PHI sebagaimana diatur UU No. 2 Tahun 2004 sudah tercermin pelaksanaan asas Equality Before the Law, seperti ketentuanketentuan tentang biaya perkara, sumpah hakim, pengajuan gugatan, penyempurnaan gugatan, kuasa hukum, majelis hakim, cara pemerkisaan/persidangan dan upaya hukum.

Namun, terdapat pula beberapa ketentuan yang justru bertentangan dengan asas 
EqualityBefore the Law, yaitu

adanya kecenderungan Pembuat

UU lebih membela kepentingan

Pekerja/ buruh. Konsep proses

beracara di PHI yang mampu

menerapkan asas Equality Before

the Law yang ideal, hanya bisa

terwujud, dengan suatu prasyarat

diatasinya/diperhatikannya

masalah-masalah, antara lain: (a)

Perbedaan kemampuan ekonomi (adanya faktor biaya), khususnya berkaitan dengan pengajuan

gugatan, kuasa hukum, lama/waktu

proses persidangan dan upaya

hukum;

(b) perbedaan

kewajiban/kepemilikan dan

penyimpanan dokumen, khususnya

berkaitan dengan beban

pembuktian (baik surat/dokumen

maupun saksi). Dalam pembuktian

surat-surat, bahan-bahan

pembuktian lebih banyak berada pada pihak pengusaha, seperti dokumen perjanjian kerja, upah, absensi dan lain-lain; dan (c) perbedaan dalam kewenangan pengelolaan SDM. Hal ini berakibat pada kemudahan pengusaha menghadirkan saksi dibandingkan pekerja/buruh (perlu ijin pengusaha).

\section{Daftar Pustaka}

Johan Utama, Yos, Menggugat Fungsi PTUN Sebagai Salah Satu Akses WN untuk mendapatkan Keadilan dalam Perkara Adm.Neg. Jurnal Hukum Vol. 10 No. 1.Maret 2007

Pangaribuan, Juanda, 2011, Kedudukan Dosen dalam Hukum Ketenagakerjaan, Jakarta: Bumi Intitama Sejahtera.

Rimdan, 2012, Kekuasaan Kehakiman Pasca-Amandemen Konstitusi, Jakarta: Kencana Prenada Media Group.

Shidarta, Arief, 22-24 Juni 2011, Sebuah Catatan tentang Hakim, Makalah pada Lokakarya Peningkatan Kapasitas Hakim, Hotel Apita, Cirebon 
Venn Divey, Albert, 1915, Introduction to the Study of the Law of the Contitution, London: Mcmilian

Saleh, M. \& Lilik, 2012, Seraut Wajah Pengadilan Hubungan Industrial, Bandung: Citra Aditya Abadi

\section{Peraturan Perundang-Undangan:}

Undang-Undang Dasar Negara

Republik Indonesia tahun 1945,

Undang- Undang No. 21 Tahun 2000

Tentang Serikat Pekerja/Serikat Buruh.

Undang- Undang No. 13 Tahun 2003

Tentang Ketenagakerjaan.

Undang-Undang No. 2 Tahun 2004

Tentang Penyelesaian Perselisihan

Hubungan Industrial.

Undang-Undang No. 48 Tahun 2009

Tentang Kekuasan Kehakiman.

Undang-Undang No. 49 Tahun 2009

Tentang Peradilan Umum.

Undang-Undang No. 30 Tahun 1999

Tentang Arbitrase dan Alternatif

Penyelesaian Sengketa 